\title{
State formation and international behaviour
}

\section{Primitive state-building}

State-building is the effort of rulers to institutionalise state structures capable of absorbing expanding political mobilisation and controlling territory corresponding to an identity community. In the Middle East, the flaws built into the process from its origins have afflicted the states with enduring legitimacy deficits (Hudson 1977). Because imperialism drew boundaries that haphazardly corresponded to identity, installed client elites in them and created the power machineries of the new states, state elites, long after independence, continued to depend on external protection and on resources provided by external powers or markets rather than raised domestically through consent; as such, most Middle East states were and remain relatively less accountable to domestic society than where they are indigenous products.

State-building was accompanied by class conflict because imperialism had fostered dominant classes that privately appropriated the means of wealth production, notably land at the expense of peasantries or natural resources (petroleum), stimulating plebeian revolts and political mobilisation which fragile state structures could not initially contain. Later, state-building meant the expansion and indigenising of imported instruments of rule used in 'primitive power accumulation', a typically violent process entailing the cooptation of some social forces and the exclusion of others. Only gradually after 1970 did many individual states come to enjoy increased stability as rentier monarchies and authoritarian republics were relatively consolidated as the two dominant forms of state in the Arab world. Neither type of regime, however, effectively resolved 
the legitimacy deficit for both tended to centre on exclusivistic tribal, personalistic or ethnic ruling cores, generated new, privileged, statedependent classes, and either brought the mass of citizens to trade political rights for socio-economic entitlements or repressed their demands for political participation. Such patterns of state formation are likely to have profound consequences for foreign policy: if the state itself is contested, foreign policy may entail its defence as much against internal as external threat; if little welfare or political rights are delivered, precarious legitimacy is exceptionally dependent on the nationalist or Islamic credibility of foreign policy (Dawisha 1990).

\section{Aspects of state formation}

This study will argue that several aspects of state formation are pivotal in determining the international behaviour of states and specifically to explaining variations in their foreign policies.

(1) The circumstances of a state's initial composition tend to set it on a particular foreign policy tangent, either status quo or revisionist. (a) Because state formation is coterminous with a contested process of identity construction, whether a state's boundaries satisfy or frustrate identity shapes its foreign policy role. During the initial formation of the states system, imperialist boundary drawing literally built irredentism into many states; however where indigenous state-builders were able to achieve some correspondence between the dominant political identity and the state's boundaries, as for example in Turkey and Saudi Arabia, foreign policy has been relatively free of irredentist revisionism. (b) Because primitive state formation always involves some degree of inclusion and exclusion, whether the specific social forces incorporated at the founding of regimes were largely satisfied (privileged) or dissatisfied (plebeian) also tends to set states on opposing status quo or revisionist tangents. Specifically, those, often monarchies, forged around traditional satisfied classes implanted, penetrated and supported by the Western 'core' were biased toward status quo policies, while the wave of revolt against this, in which states were captured from below by dissatisfied plebeian forces and turned into radical republics, infused revisionist ideology into many states' foreign policies, at least until radical elites, becoming new classes, acquired stakes in the status quo. 
(2) The level of state formation (or consolidation) shapes the rationality and effectiveness of states' foreign policies. Rationality in foreign policy denotes reason of state, that is, the choice of ends through a cost-benefit calculation and the matching of ends with means: scaling down ambitions to match capabilities and/or building up capabilities to sustain ambitions. Effectiveness denotes the capacity to implement policies. Arguably, state consolidation depends on some balance between the institutionalisation of state structures and the incorporation of mobilised social forces into them (Huntington 1968). A balance endows elites with both sufficient autonomy to make rational choices and sufficient legitimacy and structural capacity to mobilise the support and extract the resources to sustain these choices.

Traditional states (landed oligarchies, tribal monarchies) with both low levels of political mobilisation and institutionalisation may face limited opposition to their foreign policies at home but lack the ability to mobilise support and resources there needed to project power abroad. Consolidated states, with high levels of mobilisation incorporated into strong institutions, enjoy both domestic support and the military capabilities to be formidable foreign policy actors (Israel with its citizen army). For a long time, most Middle Eastern states have suffered from one or another type of structural imbalance. Where there is insufficient institutionalisation to organise mobilisation (praetorian regimes), the main threat to states may be domestic and the 'domestic vulnerability model' of foreign policy may hold in which policy is chiefly designed to contain internal instability by exaggerating an external enemy or indulging in antiimperialist rhetoric (Calvert 1986; David 1991). Where, in reaction to this, neo-patrimonial strategies, combining modern and traditional power techniques, were used to 'over-develop' state control structures at the expense of political participation, elites were buffered from accountability; this may be compatible with the 'leadership dominant model' which assumes leaders face few institutional constraints at home and can translate their personal values, styles and pathologies - into foreign policy (Clapham 1977). In either case, foreign policy is arguably more likely to lack rationality and effectiveness.

The traditional, praetorian, neo-patrimonial and consolidated models may best be seen as four ideal types reflective of extreme cases. Actual regimes may more or less approximate one or a 
combination of these models. Most important, a number of scholars argue that, after several decades of state-building in the region, partly consolidated regimes (combining aspects of the consolidated with one or more of the other models), have become typical (Dawisha and Zartman 1988; Mufti 1996: 9-16). Arguably, these regimes are sufficiently institutionalised that foreign policies are less directly shaped by the unconstrained biases of the top leader or by internal instability and more by the external challenges which have become so salient.

(3) Finally, the affect of the structural type of the state - specifically its authoritarian or democratic/pluralist character - on foreign policy behaviour needs to be tested in the Middle East. Democratic states, if consolidated, are likely to be strong foreign policy actors. But those claiming that democracies are more pacific are disputed by the argument that transitional democracies may actually be more susceptible to war (Mansfield and Snyder 1995) and by Middle East evidence that 'irredentist democracies' are particularly belligerent while authoritarian regimes may be either status quo or revisionist.

\section{The phases of state-building}

State-building in the Middle East has varied considerably over time. ${ }^{1}$ Four identifiable stages in Arab state formation are adumbrated below, with comparisons to the non-Arab states made where appropriate. At each stage, the formation of the individual states is a product of interaction between internal political forces and the simultaneously developing systemic (international and regional) structures in which the states are embedded. State formation, in turn, is a major determinant of the foreign policy behaviour of the individual states, for, as will be argued, at each stage in state formation different kinds of foreign policies are typical.

\section{Stage 1: Pre-consolidated traditional states (1920s-1948)}

The pre-consolidation traditional era in the Arab world was one of weak states governed by semi-independent, narrowly based, oligarchic republics, monarchies or dictatorships ruling over small albeit mobilising middle classes and unmobilised masses. The colonial powers had, in many countries, imposed borders, bureaucracies and formally liberal institutions (parliaments, elections) and fostered or co-opted the landed-commercial notability (ayan) out of which the 
first-generation nationalist elites arose. These elites represented a thin upper stratum linked to society mostly through urban patronage networks and control of landed estates; reluctant or unable to mobilise sustained mass resistance to the imperialist powers, they could not avoid compromises with them (e.g. permitting bases, treaties) in return for formal independence which, together with irredentist dissatisfaction with borders, invariably tarnished their legitimacy.

For the Arab states, the continued presence of imperial powers in the region, extreme economic dependence and limited military capabilities meant the international system sharply constrained state options. As long as societies were unmobilised, domestic constraints were weaker, yet owing to intra-elite fragmentation and low institutionalisation many regimes were too unstable and narrow-based to conduct rational or effective foreign policies. Policy tended to take one of two paths: either rhetoric meant to appease domestic opposition or efforts to secure outside security guarantees against it. By contrast, Turkey, Israel and Iran, more the products of indigenous state-builders than foreign imperiums, enjoyed the greater legitimacy that made possible more (although by no means wholly) inclusive states. In Turkey and Israel, the combination of democratic legitimacy and institutionalisation gave leaders the autonomy in foreign policy making needed to pursue policies resembling classic reason of state and directed chiefly at perceived external threats. This unevenness of state formation, issuing from the earlier independence of Turkey and the transplant of a mobilised Zionism into the region meant the Arab states confronted much stronger non-Arab opponents.

\section{Stage 2: Preconsolidation praetorianism and divergent paths:} revolutionary republics, traditional survival (1949-70)

The Palestine War, the struggle to throw off imperialism and the Arab-Israeli conflict rapidly accelerated political mobilisation in the Arab region, ushering in the next, praetorian stage. Nationalist politicisation dovetailed with middle-class demands for a share of power and labour and peasant ferment over the region's highly unequal forms of capitalist development. Presidents and kings sought to concentrate power but, given the weakness and fragmentation of status quo parties and parliaments and the manipulation of elections, their weakly institutionalised regimes could not sufficiently incorporate the rising middle class to stabilise the state. 
Political mobilisation came instead through radical ideological parties which turned the newly mobilised against the semi-liberal oligarchic political order. The recruitment of the radicalised middle class into the army led to widespread military intervention in politics which destroyed the rule of the notables in several of the settled, more developed societies and opened the door to praetorianism - an era of factional struggle for power marked by coups and countercoups which lasted until the 1970s. In a few settled societies (Jordan, Morocco), external support or exceptional leadership allowed the old order to survive while in the less-developed Arabian peninsula, persistent tribalism, the smallness of the educated class and/or continuing British tutelage delayed these tendencies.

By the 1960's (earlier in Egypt) and peaking in the 1970s, statebuilding was underway across the region. It was initially driven by the need to master domestic instability and trans-state penetration and/or to dilute international dependency. However, state-building put states on quite different (status quo or revisionist leaning) foreign policy tangents. The main root of this differentiation was the impact of imperialism. Where the length and intensity of the independence struggle radicalised social forces (as in Egypt or Aden) or where the imposition of the regional state system thwarted indigenous interests and identity (whether creating 'artificial' states in Syria and Iraq or leaving irredentist ambitions unsatisfied), the dominant status quo social forces were weakened and more radical, middle-class or even plebeian forces were mobilised in the struggle for power. Where this issued in revolutionary coups, the new regimes harnessed foreign policy to the revisionist sentiments of the social forces they incorporated. Conversely, the more the new states relatively satisfied indigenous interests and identity, as in Turkey or Saudi Arabia, or where independence was achieved without political mobilisation (the Arab Gulf), the more status quo elites survived and newly independent states followed policies accommodating themselves to the West.

Although there were exceptions, the resultant regimes, differentially incorporating satisfied or dissatisfied social forces, tended to pursue one of two quite different archetypal state-building strategies. Traditional monarchies tended to survive in small-population, unmobilised (or communally divided) societies, mostly in the Arabian Peninsula. Tribal chiefs-turned-state-elites sought legitimacy through traditional versions of Islam and the manipulation of tribal and 
kinship links now reinforced by the creation of new bureaucracies and Western or oil-financed patronage. The main threat was from Egyptian sponsored Pan-Arabism, which found resonance among the small but dissatisfied middle and working classes (typically in the petroleum sectors). These geo-politically weak states required Western protection from regional threats, but, in the Pan-Arab era of relative Western rollback from the region, needed also to appease trans-state and domestic Arab nationalist opinion; this resulted in policies which wavered between close Western alignment and a distancing from Western patrons in times of crisis or which used symbolic politics - such as the banner of Islamic solidarity - to disguise Western dependence and counter Pan-Arabism. The exception was Iran's larger more mobilised society where the Shah had to construct a more elaborate technology of control, heavily dependent on clientalism, repression and external backing.

In the authoritarian-nationalist republics, where regimes originated in middle-class overthrow of Western client elites by nationalist officers, state formation meant the wholesale reconstruction of states against the opposition of the displaced upper classes and amidst Western hostility, requiring, therefore, a measure of mobilised popular support. Charismatic presidents rose to power through the army but directly appealed to the mass public. Especially in those republics lacking oil, popular support and autonomy of the dominant classes were sought through wealth re-distribution (e.g. land reform) and statist development based on nationalisations and a public sector. Economic dependency was eased or diversified as state control of economic links to the world market displaced client classes while aid and markets were accessed in the Eastern bloc. These regimes attempted, with some success, to incorporate the new middle classes, the organised working class and land-reform peasants. But because the military remained the main vehicle of factional politics, because these regimes lacked a secure social base in a dominant class, and because opposition persisted among the traditional landed, tribal and commercial elites and their often-Islamic followers, the republics remained unstable. Possessing neither traditional nor democratic legitimacy, they sought legitimisation in radical nationalism: hence foreign policy took the form of anti-imperialist and anti-Zionist rhetoric while bi-polarity provided the necessary conditions for these policies: protection from Western intervention.

Because military power-projection capabilities remained limited, 
while the Arab states, Egypt aside, were vulnerable to trans-state ideological penetration, the main threat elites faced was domestic opposition exacerbated by external subversion (Maddy-Weitzmann 1993). Foreign policy was chiefly shaped by its expected domestic consequences in the legitimacy contest between the radical PanArab and conservative camps. The divergent strategies of the rival camps had their own risks and costs. The monarchies' search for external protection against domestic opposition only exacerbated nationalist rejection of them, most evident in Iraq where the regime's identification with the Baghdad Pact was its undoing; but appeasing Pan-Arabism also held its dangers, as when King Hussein was swept into the 1967 war. In the republics, playing the nationalist card risked Western-backed intervention, subversion and/or Israeli attack, most notable against Syria during the 1950s. Finally, the nationalist outbidding of regimes over the Palestine issue that the 'Arab Cold War' encouraged (Kerr 1971), prepared the way for the 1967 war, which opened an era of 'hot wars' that would have a profound effect on state formation.

\section{Stage 3: Semi-consolidation and convergence (1970-1980s)}

A third stage was apparent by the 1970 s, namely the increased, albeit incomplete, consolidation of both monarchies and republics. The incentive for state consolidation against domestic threats was now reinforced in key cases by high external military threat (particularly for the front-line Arab states in the conflict with Israel and later with Iran). In making war, states 'constructed' a regional system fraught with insecurity, which, in turn, precipitated a reconstruction of the states in ways allowing their survival in this dangerous environment. Military threat spurred advances in defensive state formation and a preoccupation with the accumulation of power needed to balance against threats. Wars precipitated the oil price explosions that gave states the means to consolidate themselves and expand their military capabilities, which, however, only increased the security dilemma for each individual state. Against this threatening regional background, state-builders deployed dual 'modern' and 'traditional' strategies (Tripp 1996) that blurred the difference between republics and monarchies. The resultant regimes moved away from both the 'traditional' and 'praetorian' scenarios toward semi-consolidated mixtures of the 'neo-patrimonial' and 'consolidated' models in the following key ways. 
(1) The character of leadership shifted within regimes from radical demagogues and populist leaders challenging the status quo to national security specialists - pragmatic generals, technocrats and intelligence operatives - obsessed with stability.

(2) Executive centres were institutionalised and ruling elites became more cohesive. While oil patronage reinforced the solidarity of large extended ruling families in the monarchies, in the republics, years of intra-elite factional conflict were overcome by the emergence of dominant leaders ensconced in virtual 'presidential monarchies' endowed with cults of personality. Crucial to this was the use of traditional sectarian, tribal and family assabiya to create cores of trusted followers around the leader similar to royal families in the monarchies.

(3) In their search for legitimisation, state elites made use of sub- and supra-state identities to make up for thin popular identifications with the state itself. In the monarchies patriarchal loyalties and Islam were the favoured formula; in the republics Pan-Arabism, the official ideology, was buttressed by the exploitation of sub-state loyalties, whether it was Tikriti solidarity in Iraq or that of the Alawis in Syria.

(4) There was a widespread expansion of bureaucratic structures and the modern means of coercion and communications. In the republics, presidents commanded expanding bureaucratic pillars of power - army, bureaucracy, party and mukhabarat. In these regimes, which had emerged from military coups, the military remained the core pillar of power, but its disciplining and relative depoliticisation, achieved through a combination of purges, controlled recruitment, intelligence surveillance, privileges and professionalisation (driven by the need to counter external military threats), turned armies from sources of coups into reliable chains of command. Ruling parties developed from small cliques into Leninist-like single or dominant party apparatuses, loosely modelled on those in the East bloc, of impressive size, complexity and functions, which now penetrated the rural peripheries of society and were better able to incorporate large cross-class bases of support. Corporatist structures such as professional associations afforded control over the upper-middle and middle classes. Where political parties did not exist, as in the oil monarchies, enormous extended ruling families acted as surrogate single-party systems while their use of tribal networks to funnel patronage downwards was analogous to the corporatist structures of 
the republics. Intelligence and security apparatuses, commanding greater technology and manpower, proliferated in both kinds of state: the 'mukhabarat state' had arrived. Thus, in both types of state, inherited patrimonial strategies of control were grafted onto modern technology and political organisation.

(5) Increased state penetration of society was reflected in heightened government control of resources. As measured by government expenditure as a percentage of GDP, Egypt pioneered the process with a rise from 37 per cent in 1952 to 70 per cent in 1968 and 81 per cent in 1974 - a function of statism and war thereafter declining to 40-50 per cent. Syria, Iraq and Saudi Arabia only reached such levels in the 1970s and 1980s (Gause 1992: 460). While this reflected, to a degree, the ability to collect oil rent and disguised a limited ability to extract taxes from society, it nevertheless gave regimes autonomy of society and made good parts of the population dependent on the state. State-sponsored education, aiming to inculcate political loyalties as well as skills, increased dramatically in all states: from 1955 to 1980 the percentage of primary and secondary school age children in the school system increased from 24 per cent to 89 per cent in Iraq, from 51 per cent to 91 per cent in Jordan and from 4 per cent to 48 per cent in Saudi Arabia (Gause, 1991: 16). There was an enormous rise in state employment. Civil bureaucracies expanded regardless of regime type. In Egypt from 1962 to 1970 the bureaucracy increased by 70 per cent. In Kuwait, the bureaucracy employed 34 per cent of the labour force in 1975 and 20 per cent in Syria in 1979. In Saudi Arabia, the civil service grew from a few hundreds in the 1950s to 245,000 in 1979-80 (Ayubi 1988: 15-19). The more effective control that this structural proliferation afforded over the territories of states made them less permeable and susceptible to trans-state ideological penetration.

(6) Movement toward state consolidation was associated with the creation of new state-dependent classes, attaching to state structures the strategic class interests needed to anchor them against the winds of trans-state popular sentiment. The expanding bureaucratic strata's command of public resources gave them stakes in the particular interests of their individual states. In the republics, the old landed-commercial bourgeoisie was eclipsed by new state bourgeoisies with a stake in the status quo and by the subsequent transformation of part of the surviving middle-sized business sectors into 
dependent clienteles thriving on state monopolies, commissions, contracts and inputs. In the monarchies, commercial and tribal elites were similarly transformed via state patronage into new bourgeoisies.

(7) Long-term stability also depended on incorporation of a sufficient segment of the middle and lower strata which, in turn, depended on sufficient economic resources to give them a stake in the status quo. In monarchies and republics alike, regimes forged a sort of populist social contract: in return for support or acquiescence, the state provided jobs, free education, subsidised foodstuffs and labour rights. In the republics, this initially relied on the 'socialist' redistribution of upper-class assets but with the oil price boom it could be funded more generously. In the monarchies, the one-time threat from the growing new middle class was contained by coopting it into state jobs but excluding it from the military.

Advances in state consolidation had foreign policy consequences. Top elites, their power relatively consolidated and able to balance conflicting social forces, generally attained hitherto lacking autonomy of society in the making of foreign policy. How far this resulted from a better balance between institutionalisation and participation or from the neo-patrimonial de-mobilisation of civil society is an empirical question that varies by case. Generally, however, this elite autonomy, combined with increased regime stability, declining vulnerability to trans-state ideology and rising threats from neighbouring states, issued in increased weight being given to geopolitical reason of state over identity issues in foreign policy making. This meant more prudent and effective policies, but also a certain sacrifice of longer-term Pan-Arab interests to more immediate individual state interests. Power capabilities generally increased as oil rent enabled states to make exceptional arms purchases, stimulating arms races. Additionally, the increased oil resources and military capabilities of regional states made them more autonomous of external great powers. As the threat from neighbouring states increased, more remote international powers were seen less as threats and more as sources of protection and resources in the regional struggle.

These tendencies spelled a significant convergence in the policies of monarchies and republics. In the republics, radical elites, either displaced or chastened by defeat in war, moderated their ideological radicalism. Egypt and Syria were forced, by the need to recover the 
occupied territories from Israel, to bury the ideological cold war with the monarchies, to moderate anti-Western policies and to seek a negotiated peace with Israel while, at the same time, the monarchies used oil resources to subsidise nationalist states and briefly attempted to win nationalist legitimacy by using the 'oil weapon'. Later, the Gulf monarchies would be driven by fear of Iran to seek detente with republics such as Iraq. As such, the systemic level, specifically regional threats, tended to recast states, originally very different, into similar 'realist' moulds following similar pragmatic foreign policies.

There were, however, important exceptions and counter-trends to the regional tendency toward realism and moderation. Even as Arab nationalism declined as a threat to regimes, it was replaced by a new supra-state revisionist ideology, political Islam. The 1967 war, in discrediting secular Arab nationalism, had left an ideological vacuum while the negative side effects of state-building - the corruption and inequality that oil money encouraged - turned those who felt excluded to political Islam as an ideology of protest. These factors precipitated revolution in Iran and the attempt of the Islamic republic to export its revolution, leading to war in the Gulf. This was paralleled by the rise of the revisionist Likud party in Israel which similarly led to war in Lebanon.

These developments in turn arrested the tendency toward convergence as key republics, locked into intractable conflicts on the nonArab periphery, became major 'war states'. Iraq's regime was consolidated in the crucible of the war with Iran and Syria's buttressed by the war with Israel in Lebanon. War drove an upward trajectory in the size of armies; Syria and Iraq, where wars and threat levels were the highest, achieved exceptional levels of military mobilisation - increasing from 6.4 and 6.7/1,000 pop. in 1955 to 36.2 and $62.4 / 1,000$ of population in 1987. In good part this was a necessary reaction to high levels of such mobilisation in Israel (which reached 145/1000 in 1987) and in revolutionary Iran (Gause 1992: 457-8).

As state construction matured, the once fragile republics showed an ability to survive the worst crises, including defeat in war. In 1967 Egypt and Syria survived a greater defeat than the one which brought down the ancien régimes and mobilised the power to challenge Israel in 1973; in the early 1980s, Syria survived back-to-back Islamic rebellion and conflict with an Israeli-American combinazi- 
one in Lebanon. Iraq survived the enormous pressures of the war with Iran and did not split along communal lines as might have been expected; Saddam Hussein's regime also survived the much more intense pressures applied by the US in the Gulf War and its aftermath, including military defeat, economic blockade and loss of full territorial control. By contrast, the monarchies, unable to trust the middle class, kept their armies small and recruited from extended royal families and loyal tribes. This forced them to rely for their security on high-tech oil-for-arms purchases from the West and an increasing US naval presence in the Gulf.

The main consequence of the period was the considerable extent to which the generalisation of external insecurity, state consolidation, and reason of state brought the regional system into closer approximation to the Westphalian model. It was, however, Iraq's invasion of Kuwait, injecting military insecurity into inter-Arab politics, where competition had hitherto largely remained at the political-ideological level, which crowned this process.

\section{Stage 4: State vulnerability and global penetration (1980-2000+)}

A fourth stage, whose origins can be traced back to the 1970s but which only fully emerged in the 1990s, was marked by growing economic crisis and loss of Soviet patronage in the republics and by military shock (Iran's threat, Iraq's invasion of Kuwait) in the monarchies, exposing the fragility of state-building in both. This coincidence of domestic vulnerability with major changes in the international system - the end of bi-polarity, the globalisation of capitalism - opened the door to a reconstruction of dependencies that, in the previous period, had seemed to be minimised.

The root of the new vulnerability in the republics lay in domestic economic weaknesses. Inefficient public sectors, the exploitation of economies for military ends, and populist distribution policies had enervated capital accumulation and led to the exhaustion of statist import-substitute industrialisation, driving moves to open economies to private and foreign capital: the so-called infitah. The boom/bust cycle of the international oil economy also impacted on state formation. Oil rent financed a burst of state-building that ended in overdeveloped states exceeding the capacity of their own economic bases to sustain. Enormous resources were expended on arms races. Oil rent and infitah also encouraged import booms rather than investment at home. This, combined with the 1980s oil bust, left the 
republics saddled with balance of payments crises and debt that greatly increased their vulnerability to external pressures from Western donors and to IMF demands for structural adjustment.

At the same time, a transformation in the social base of the republics was taking place, with the old populist coalition being replaced by new 'infitah (internationalist) coalitions'. The roots of this go back well before the 1990s. The authoritarian-populist state, which initially had balanced 'above' classes, in time generated a new dominant class from within. It was made up of an alliance of the 'state bourgeoisie' (formerly plebeian but embourgeoised military officers, high-paid state managers and senior bureaucrats) with a revived private bourgeoisie of contractors and middlemen doing business with the state. As the public sector was exhausted as a source of wealth and careers, the state bourgeoisie looked to economic liberalisation to diversify the state's economic base as well as provide opportunities for it to invest its accumulated wealth in private business and thereby transform itself into a property-owning class; the private bourgeoisie saw new opportunities in infitah for foreign partners and to acquire public sector assets. The revival of private capitalism, first initiated by Sadat in Egypt, spread across the region. Many states were increasingly entangled in a web of economic relations with core states, whether they were forced into export strategies to repay accumulated debt or perceived potential opportunities to secure capital inflows. This required that investors be favoured over the mass public, hence infitah was typically accompanied by a rollback in subsidies and welfare measures and the beginnings of privatisation of public sectors.

Authoritarian power structures largely persisted but whereas previously such power was used to attack privileged groups and to broaden equality, it was now deployed to protect the new economic inequalities that followed on infitah. This post-populist period is associated with uneven political liberalisation: while the interest groups of the bourgeoisie were given greater corporatist and parliamentary access to power and safety valve opposition parties for the middle class were tolerated within strict limits, mass organisations and trade unions were brought under stricter control and excluded from the access to decision-makers they often formerly enjoyed in the populist era.

Parallel alterations in the global power balance, also evident before the 1990s, reinforced domestic change to drive a nearly 
uniform Westward re-alignment in foreign policies. The declining Soviet ability to provide the Arab states with the military capability to match that given to Israel by Washington, hence the perceived indispensability of American power to ending the Israeli occupation of Arab lands, was a major factor reinforcing Egypt's repositioning in the world order; where Egypt led, others followed. The decline of the Soviet Union as an alternative market and source of technology and aid also meant, once buffering oil rent also declined, that there was no alternative to reintegration into the world capitalist market. Crucially, the collapse of the Soviet Union left the radical republics exposed, without the political protection or military patronage they needed to pursue autonomous policies that challenged Western interests.

The result was a further moderation in the foreign policies of formerly radical republics. Even as some of them had previously harnessed their economies to foreign policy, so economic troubles now drove many to harness foreign policy to the economy - that is, into the practise of 'trading' Western-friendly foreign policy for economic aid and investment. This tendency was reinforced by economic globalisation which seemed to provide new opportunities for inward investment: an attractive investment climate and re-integration into the international economy required moves toward settlement of the Arab-Israeli conflict and a Western foreign policy alignment in place of balancing between the superpowers.

A different kind of vulnerability was exposed in the oil monarchies. There, family states with tiny pampered citizen populations dependent on expatriate labour, combined great wealth with low military capability. Their chief liability was their location contiguous to much larger, poorer and militarily stronger states - Iran and Iraq. The Iran-Iraq war spared the monarchies their immediate attentions throughout the 1980s, but the Iraqi invasion of Kuwait administered a shock to these regimes that paralleled the economic crisis in the republics. It showed they could not survive in a world of powerful predatory neighbours without much enhanced Western protection. The resultant foreign policy change took the form of a much more overt Western presence (bases, treaties). Their key security interest was to maintain the flow of oil revenues needed to appease constituencies at home while enlisting the Western protection against threats from their stronger neighbours.

If the state-building of the 1970s and 1980s was driven in good 
part by external security threats, this started to decline in the $1990 \mathrm{~s}$ as enhanced Western penetration left far less scope for the ambitions of potential regional hegemons, especially after the Iraq and Afghan conflicts demonstrated a re-newed ability of the American hegemon to project power into the region. Rather, the most salient determinant of policy became the effort of regimes to balance between the increased international demands on them and domestic resistance to these demands. Regional states were becoming transmission belts for the enforcement of Westcentric globalisation at the possible expense of indigenous interests and identity: the imposition of structural adjustment, of unpopular and inequitable peace treaties with Israel, of a US campaign against terrorism and so-called 'rogue states'. This, however, spelled increased domestic risks. While the Middle East region has proven more resistant than others have to the neo-liberal rules of the international economy, even its incremental integration into this order threatens to undermine the very foundations of current states. Regimes that have built their legitimacy on a distributive social contract are being pushed toward a policy of trickle-down capitalism. At least in the short term, this is bound to leave a more or less large segment of the public marginalised. Marginalised strata are the most likely to be attracted to sub- and supra-state identities and available for anti-system mobilisation by counter-elites: indeed, the victims of economic liberalisation appear to be among the main constituents of Islamic opposition movements. If the stronger states now in place have contained and localised the political threat of such movements, the gradual Islamisation of society at the grassroots may ultimately spell longer-term indigenous resistance to the globalisation on regime agendas. Especially to the extent economic integration into the world system facilitates Western penetration of their societies, while conflict between the US hegemon and a variety of Muslim states continues to assume a high profile, regimes risk whatever Arab or Islamic legitimacy they might enjoy without yet having found a credible substitute for these suprastate identities.

Whether democratisation could serve as an alternative basis of legitimacy was not really tested. It was obstructed or limited by ruling elites' dependence on trusted in-groups or privileged classes and the consequent stunting of political institutions. Limited political liberalisation left ultimate power in the hands of the executive, while tending to disproportionately empower the educated and 
wealthy classes at the expense of the masses. However, where democratisation proceeded further, it empowered domestic reaction against the tilt toward the West and Israel, which Islamic movements exploited, prompting regimes to halt or reverse these experiments. The case of Jordan showed dramatically how a regime's responsiveness to outside demands - for peace with an Israel unwilling to concede Palestinian rights, the price of restored American aid - was necessarily paralleled by a contraction of domestic democratisation and responsiveness to domestic opinion. It also illustrated how the dependence of many states' revenue bases on aid from the West, rather than taxes from their own population, made their foreign policies more responsive to the former than to the latter. The increased penetration of Middle East states by the core, combined with the failure of democratisation, means that increasingly local states are pursuing foreign policies in the face of broad if apparently shallow opposition from their own publics.

\section{Conclusion: state formation and the system level}

At each stage the system level has been decisive in driving state formation. First, imperialism literally constructed the system and its state components. Later, two trans-state forces rooted in persisting suprastate identity - first Pan-Arabism, then radical Islam - stimulated the state formation needed to bring their subversive potential under control. Later yet, war motivated and legitimised state-formation advances and precipitated the trans-state oil flows that provided resources for it and for the militarisation that intensified the regional security dilemma. Most recently, globalisation is threatening to turn regional states from buffers against external intrusion into transmission belts of it. While these region-wide forces have shaped similar patterns of state formation, the behaviour of any individual state can only be explained by its particular state-formation path and its particular policy process, as chapters 5 and 6 will show.

\section{Notes}

1 The following account of state-formation benefits from a number of classic accounts including Anderson (1986, 1987); Ayubi (1995), especially chapters 6-10; Beblawi (1987); Berberoglu (1989); Bromley 1994: 119-54; Chaudhry (1997); Crystal (1991); Dawisha and Zartman 
(1988); Hudson (1977); Luciani (1990); Mufti (1996); Owen (1992); Richards and Waterbury (1996), chapters 7-9, 11-13; Tachau (1975); Trimberger (1978) and Zartman et. al. (1982), as well as numerous single-country studies. 